\author{
KONRAD KOPYSTYŃSKI \\ Uniwersytet Wrocławski \\ e-mail: konrad.kopystynski@uwr.edu.pl
}

\title{
Wyłączenie stosowania przepisów ustawy o swobodzie działalności gospodarczej w sprawach o cofnięcie koncesji na prowadzenie kasyna gry a ochrona interesu publicznego
}

\section{Wstęp}

W Polsce prowadzenie kasyna gry jest dozwolone dopiero po uprzednim uzyskaniu przez przedsiębiorcę stosownej koncesji na wykonywanie tego rodzaju działalności gospodarczej. Sama koncesja jest instytucją tradycyjnie zaliczaną do środków reglamentacyjnych jako akt wprowadzający daleko idące ograniczenie wolności działalności gospodarczej. Historycznie koncesja była zarezerwowana dla obszarów objętych monopolem państwa, obecnie dotyczy dziedzin działalności gospodarczej o szczególnym znaczeniu dla strategicznych interesów państwa ${ }^{1}$. Jest aktem o charakterze konstytutywnym; wraz z jej otrzymaniem koncesjonariusz nabywa bowiem uprawnienie do prowadzenia działalności gospodarczej określonego rodzaju². Podkreśla się przy tym, że koncesja w swojej istocie w znacznym stopniu oparta jest na uznaniu administracyjnym, co stanowi kolejną jej cechę charakterystyczną ${ }^{3}$. Wskazuje się wreszcie na jej osobisty charakter i towarzyszącą jej niezbywalność ${ }^{4}$.

1 T. Kocowski, Reglamentacja działalności gospodarczej w polskim administracyjnym prawie gospodarczym, Wrocław 2009, s. 273.

2 M. Zdyb, Komentarz do art. 46, [w:] M. Sieradzka, M. Zdyb, Ustawa o swobodzie dziatalności gospodarczej. Komentarz, Warszawa 2013, s. 366.

${ }^{3}$ K. Klecha, Wolność działalności gospodarczej w Konstytucji RP, Warszawa 2009, s. 250.

4 Wyrok SN z dnia 8 maja 1998 r., sygn. III ARN 34/98, OSNAP 1999, nr 5, poz. 157. 
Przesłanki cofnięcia koncesji na prowadzenie kasy zostały uregulowane przez ustawodawcę w szczególny sposób. Mówiąc o przesłankach cofnięcia, mamy na myśli okoliczności, których wystąpienie powoduje — albo też może spowodować — odebranie koncesji posiadającemu ją przedsiębiorcy. Szczególna regulacja w tym zakresie przejawia się w tym, iż do koncesji na prowadzenie kasyna gry nie mają zastosowania ogólne przesłanki cofnięcia koncesji wyrażone w Ustawie z dnia 2 lipca 2004 r. o swobodzie działalności gospodarczej ${ }^{5}$ (co jest zasadą dla innych koncesjonowanych rodzajów działalności gospodarczej). To z kolei pozwala na postawienie pytania, czy takie rozwiązanie prawne zapewnia należytą ochronę interesu publicznego, co niewątpliwie winno przyświecać ustawodawcy przy regulacji stosunków w tak problematycznej dziedzinie jak branża hazardowa. W tym miejscu podkreślenia wymaga fakt, iż tożsame rozwiązanie przyjęto wobec przesłanek przyznania koncesji na prowadzenia kasyna gry, a więc warunków, jakie musi spełnić przedsiębiorca ubiegający się o uzyskanie koncesji. W tym aspekcie także nie stosuje się przepisów ogólnych z u.s.d.g., a jedynie odrębne przesłanki zawarte w Ustawie z dnia 19 listopada 2009 r. o grach hazardowych ${ }^{6}$. Z przyczyn technicznych jednakże niniejsze opracowanie będzie dotyczyć wyłącznie przesłanek cofnięcia koncesji na prowadzenie kasyna gry i to one zostaną poddane stosownej analizie pod kątem ochrony interesu publicznego, który jest dla prawa administracyjnego pojęciem absolutnie kluczowym i często materializuje się w wykorzystywanych przez ustawodawcę klauzulach generalnych, sprowadzających się w swojej treści do nakazu zapewnienia jego należytej ochrony?

Należy mieć przy tym na uwadze, iż wzgląd na interes publiczny jest już jedną z konstytucyjnych przesłanek ograniczenia wolności działalności gospodarczej. Stosownie bowiem do brzmienia art. 22 Konstytucji $\mathrm{RP}^{8}$ ograniczenia takie można wprowadzać tylko w drodze ustawy i wyłącznie ze względu na ważny interes publiczny. Już choćby to świadczy o istotnym związku pomiędzy zasadą wolności gospodarczej, z jednej strony, a realizacją interesu publicznego z drugiej. Można wskazać, że np. Bogusław Banaszak wykorzystał pojęcie interesu publicznego dla samego zdefiniowania konstytucyjnej zasady wolności gospodarczej, która dla niego sprowadza się do

swobody podejmowania i prowadzenia działalności gospodarczej w dowolnie wybranych formach prawnych oraz na zasadzie samodzielności, chociaż bez naruszenia interesów publicznych ${ }^{9}$.

5 Dz.U. z 2016 r. poz. 1829; dalej: u.s.d.g.

${ }^{6}$ Dz.U. z 2016 r. poz. 471; dalej: u.g.h.

${ }^{7}$ A. Żurawik, Klauzula interesu publicznego w prawie gospodarczym krajowym $i$ unijnym, „Europejski Przegląd Sądowy” 2012, nr 12, s. 24.

8 Dz.U. z 1997 r. Nr 78, poz. 483.

9 B. Banaszak, Konstytucja Rzeczypospolitej Polskiej. Komentarz do art. 20, Warszawa 2012, nb. 4. 


\section{Definicje gier hazardowych}

Aktem prawnym regulującym warunki urządzania gier hazardowych i działalności gospodarczej w tym zakresie jest wskazana wcześniej ustawa o grach hazardowych. Zgodnie z dyspozycją art. 6 ust. 1 u.g.h. „działalność w zakresie gier cylindrycznych, gier w karty, gier w kości i gier na automatach może być prowadzona po uzyskaniu koncesji na kasyno gry", z zastrzeżeniem wyjątków przewidzianych w ustawie, tj. gier na automatach oraz gry w pokera, które mogą być organizowane również poza kasynami gry, w tym przez Internet. We wzmiankowanej ustawie zawarto także legalne definicje wskazanych rodzajów gier; i tak grami cylindrycznymi są:

gry losowe o wygrane pieniężne lub rzeczowe, których wynik w szczególności zależy od przypadku, uczestniczy się w nich przez wytypowanie liczb, znaków lub innych wyróżników, a wysokość wygranej zależy od określonego z góry stosunku wpłaty do wygranej, zaś wynik gry ustalany jest za pomocą urządzenia obrotowego (art. 2 ust. 1 pkt 4 u.g.h.),

grami na automatach są:

gry na urządzeniach mechanicznych, elektromechanicznych lub elektronicznych, w tym komputerowych, o wygrane pieniężne lub rzeczowe, w których gra zawiera element losowości, [...] gry na urządzeniach mechanicznych, elektromechanicznych lub elektronicznych, w tym komputerowych, organizowane w celach komercyjnych, w których grający nie ma możliwości uzyskania wygranej pieniężnej lub rzeczowej, ale gra ma charakter losowy (art. 2 ust. 3 i 5 u.g.h.).

Wreszcie grami w karty są ,gry black jack, poker i baccarat, jeżeli są rozgrywane o nagrody pieniężne lub rzeczowe" (art. 2 ust. 5a u.g.h.). Ustawodawca natomiast zrezygnował z dokładnego zdefiniowania gier w kości, wskazując jedynie, iż są to gry losowe, tj. ,gry o wygrane pieniężne lub rzeczowe, których wynik w szczególności zależy od przypadku" (art. 2 ust. 1 pkt 6 u.g.h.).

Zasadą jest zatem, iż wykonywanie działalności gospodarczej w zakresie urządzania wymienionych gier hazardowych jest dopuszczalne po uprzednim uzyskaniu od właściwego organu (tj. ministra do spraw finansów publicznych) w formie decyzji administracyjnej koncesji na prowadzenie kasyna gry. Objęcie tej dziedziny działalności gospodarczej koncesjonowaniem jest pokłosiem przyjęcia, iż wspomniana sfera pozostaje kluczowa dla państwa z uwagi na jego strategiczne interesy. Wykonywanie takich rodzajów działalności gospodarczej obwarowano wymogiem otrzymania koncesji, a więc aktu reglamentacyjnego w największym stopniu ingerującego w konstytucyjną zasadę wolności gospodarczej (przy pominięciu instytucji monopolu prawnego). 


\section{Przesłanki cofnięcia koncesji na prowadzenie kasyna gry na tle regulacji ustawy o swobodzie działalności gospodarczej}

Przepisy u.g.h. określają okoliczności, których zaistnienie aktualizuje kompetencję właściwego organu do cofnięcia udzielonej danemu przedsiębiorcy koncesji (przesłanki cofnięcia koncesji). Cofnięcie koncesji powoduje, iż koncesjonariusz traci prawo do wykonywania koncesjonowanej działalności ${ }^{10}$. Cofnięcie może nastąpić w całości lub w części, przy czym cofnięcie koncesji na prowadzenie kasyna gry w części oznacza „zawężenie jej treści w odniesieniu do zakresu określonego w wydanej koncesji" ${ }^{11}$ i może przykładowo dotyczyć ilości lub rodzajów gier w danym kasynie gry.

Przesłanki cofnięcia koncesji na prowadzenie kasyna gry zawarte są w wyczerpującym katalogu ujętym w art. 59 ust. 1 u.g.h. Co istotne, mają one specyficzny charakter, nie uzupełniają bowiem w tym zakresie na zasadzie lex specialis unormowania ogólnego z u.s.d.g., tylko w całości je zastępują. Co prawda u.s.d.g. zawiera $\mathrm{w}$ art. 58 własny katalog przesłanek cofnięcia koncesji, jednakże w tym wypadku regulacja ta jest wyłączona wobec brzmienia art. 32 ust. 6 u.g.h., zgodnie z którym „w sprawach dotyczących udzielenia, odmowy udzielenia, zmiany i cofnięcia koncesji na prowadzenie kasyna gry nie stosuje się przepisów u.s.d.g.". Należy zaznaczyć, iż jest to sytuacja wyjątkowa, albowiem w odniesieniu do wszystkich pozostałych koncesjonowanych rodzajów działalności gospodarczej zastosowanie znajdą zarówno przesłanki cofnięcia koncesji zawarte u.s.d.g., jak i przesłanki odrębnie ustanowione przepisami ustaw szczególnych. Podkreśla to tylko, jak bardzo restrykcyjnie ustawodawca podszedł do uregulowania sytuacji związanej z urządzaniem gier hazardowych i prowadzeniem działalności gospodarczej w tym zakresie, czyniąc u.g.h. jedynym źródłem prawnym kształtującym przesłanki cofnięcia przedmiotowej koncesji.

Powyższe skłania do porównania obydwu regulacji, tj. reżimu z u.s.d.g. oraz u.g.h. Pozwoli to stwierdzić, czy rzeczywiście rozwiązanie zaproponowane mocą art. 32 ust. 6 u.g.h. w zakresie przesłanek cofnięcia koncesji skutkuje zapewnieniem większej ochrony interesu publicznego przy wykonywaniu przez podmioty prawa prywatnego działalności w dość specyficznej i problematycznej branży, jaką tradycyjnie jest rynek gier hazardowych. Jak można zasadnie przypuszczać, taki był właśnie cel uchwalenia obecnie obowiązującej ustawy o grach hazardowych. Poprzednie przepisy (tj. Ustawa z dnia 29 lipca 1992 r. o grach i zakładach wzajem-

10 C. Kosikowski, Ustawa o swobodzie działalności gospodarczej. Komentarz, Warszawa 2009, s. 246.

11 R. Kamionowski, [w:] M. Bik et al., Gry hazardowe. Komentarz do u.g.h., Warszawa 2013, s. $162,165$. 
nych ${ }^{12}$ ) nie przewidywały bowiem obowiązku uzyskania koncesji dla przedsiębiorców hazardowych, poprzestając jedynie na konieczności posiadania odpowiedniego zezwolenia, które kwalifikuje się powszechnie jako akt reglamentacyjny w znacznie mniejszym stopniu ograniczający sferę wolności gospodarczej niż koncesja.

Przechodząc do omówienia przesłanek cofnięcia koncesji na prowadzenie kasyna gry, należy wskazać, iż ich zestawienie obejmuje swoją treścią art. 59 ust. 1 u.g.h., natomiast przesłanki dotyczące co do zasady każdego rodzaju koncesji zawarte są $\mathrm{w}$ art. 58 u.s.d.g. Dzieli je on dodatkowo na te o charakterze obligatoryjnym (art. 58 ust. 1-2) i fakultatywnym (art. 58 ust. 3 - przy czym podział ten jest o tyle wątpliwy, iż również w tym przypadku część przesłanek fakultatywnych doktryna uważa za de facto obligatoryjne, np. zagrożenie obronności lub bezpieczeństwa państwa lub obywateli), a także na przesłanki wiążące się z cofnięciem koncesji lub tylko zmianą jej zakresu (art. 58 ust. 2-3) oraz przesłanki wyłącznie powodujące cofnięcie koncesji (art. 58 ust. 1).

Do przesłanek cofnięcia koncesji na prowadzenie kasyna gry zaliczymy zatem:

1) nieusunięcie w wyznaczonym terminie stanu faktycznego lub prawnego niezgodnego z przepisami regulującymi działalność objętą koncesją lub z warunkami określonymi w koncesji lub regulaminie;

2) rażące naruszenie warunków określonych w koncesji, regulaminie lub innych określonych przepisami prawa warunków wykonywania działalności, na którą udzielono koncesji;

3) obniżenie kapitału zakładowego spółki poniżej kwoty 4000000 zł;

4) rezygnacja $z$ działalności objętej koncesją;

5) trwająca dłużej niż 6 miesięcy przerwa w prowadzeniu działalności objętej koncesją;

6) skazanie na terytorium państwa członkowskiego Unii Europejskiej lub państwa członkowskiego Europejskiego Stowarzyszenia Wolnego Handlu (EFTA) strony umowy o Europejskim Obszarze Gospodarczym osoby będącej akcjonariuszem (wspólnikiem), członkiem organów zarządzających lub nadzorczych spółki za przestępstwo związane z praniem pieniędzy oraz finansowaniem terroryzmu;

7) dwukrotne stwierdzenie uczestnictwa w grach hazardowych osoby poniżej 18. roku życia, w tym samym ośrodku gier lub punkcie przyjmowania zakładów wzajemnych;

8) niewykazanie przez koncesjonariusza zgodności jego działań z właściwymi przepisami regulującymi przeciwdziałanie praniu pieniędzy oraz finansowanie terroryzmu;

9) nieprzedstawienie przez koncesjonariusza sprawozdania finansowego wraz $\mathrm{z}$ opinią biegłego rewidenta zgodnie z art. 55 ust. 3 albo przedstawienie opinii wskazującej na istotne naruszenia przepisów o rachunkowości;

12 Dz.U. z 2004 r. poz. 27 z późn. zm. 
10) prowadzenie działalności przez koncesjonariusza zobowiązanego do ustanowienia przedstawiciela bez przedstawiciela przez okres dłuższy niż 2 miesiące.

Z kolei ogólne przesłanki cofnięcia koncesji z u.s.d.g. obejmują:

1) wydanie prawomocnego orzeczenia zakazującego przedsiębiorcy wykonywania działalności gospodarczej objętej koncesją;

2) niepodjęcie przez przedsiębiorcę w wyznaczonym terminie działalności objętej koncesją mimo wezwania organu koncesyjnego lub trwałe zaprzestanie wykonywania działalności gospodarczej objętej koncesją;

3) rażące naruszenie warunków określonych w koncesji lub innych warunków wykonywania koncesjonowanej działalności gospodarczej, określonych przepisami prawa;

4) nieusunięcie $w$ wyznaczonym terminie stanu faktycznego lub prawnego niezgodnego z warunkami określonymi w koncesji lub z przepisami regulującymi działalność gospodarczą objętą koncesją;

5) zagrożenie obronności lub bezpieczeństwa państwa lub bezpieczeństwa obywateli;

6) wydanie decyzji o stwierdzeniu niedopuszczalności wykonywania praw z udziałów albo akcji przedsiębiorcy na podstawie przepisów Ustawy z dnia 24 lipca 2015 r. o kontroli niektórych inwestycji;

7) ogłoszenie upadłości przedsiębiorcy.

W pierwszej kolejności wymaga odnotowania, iż wymienione przesłanki dotyczące naruszenia warunków wykonywania koncesjonowanej działalności gospodarczej o charakterze rażącym (pkt 3) lub „zwykłym” po uprzednim wezwaniu organu (pkt 4) mają swoje odpowiedniki w u.g.h., kolejno w art. 59 ust. 1 pkt 1-2, a ich dyspozycje nie różnią się istotnie. Tytułem uzupełnienia można wskazać jedynie, że „rażącym” naruszeniem warunków wykonywania koncesji nazwiemy takie, które jest „wyraźne, oczywiste, niewątpliwe, bezsporne” 13 , a więc widoczne prima facie, niewymagające dla jego stwierdzenia pogłębionej refleksji prawnej. Wzmiankowana ustawa nie wymienia za to wśród okoliczności skutkujących cofnięciem koncesji na prowadzenie kasyna gry wydania prawomocnego orzeczenia zakazującego koncesjonariuszowi wykonywania działalności gospodarczej objętej koncesją. Jest to jednak zrozumiałe, biorąc pod uwagę, iż koncesjonariuszem w tym wypadku nie może być osoba fizyczna, a jedynie przedsiębiorca zorganizowany w formie spółki kapitałowej prawa handlowego. Przedmiotowe orzeczenie natomiast siłą rzeczy musi odnosić się wyłącznie do osób fizycznych. Jego podstawą może być art. $41 \S 2$ k.k., konstytuujący środek karny w takiej postaci, lecz także art. 373 ust. 1 lub 3 bądź art. 374 ust. 1 Ustawy z dnia 28 lutego 2003 r. - Prawo upadłościowe ${ }^{14}$. Trzeba przy tym zauważyć, że również Ustawa z dnia

13 Wyrok WSA w Gorzowie Wlkp. z dnia 21 lipca 2011 r., sygn. II SA/Go 4/11, Legalis nr 582531 .

14 Dz.U. z 2016 r. poz. 2171; dalej: p.u. 
28 października 2002 r. o odpowiedzialności podmiotów zbiorowych za czyny zabronione pod groźbą kary ${ }^{15}$ nie przewiduje takiej sankcji wobec osób prawnych.

Interesująco natomiast pod kątem porównawczym wygląda unormowanie przesłanki z art. 58 ust. 1 pkt 2 u.s.d.g., dotyczącej niepodjęcia lub trwałego zaprzestania wykonywania koncesjonowanej działalności gospodarczej. Nawiązanie do tych okoliczności znajdujemy w art. 59 ust. 1 pkt 4a-b u.g.h., które stanowią o rezygnacji, a także o trwającej dłużej niż 6 miesięcy przerwie w prowadzeniu działalności objętej koncesją. Jak więc widać, ustawodawca w tym przypadku zrezygnował z użycia niedookreślonego pojęcia „trwałości” zaprzestania wykonywania działalności, precyzując, iż chodzi o okres 6 miesięcy. Z drugiej strony, w dyspozycji tego przepisu jest mowa o „przerwie”, co sugeruje, że przed okresem faktycznego nieprowadzenia działalności koncesjonariusz przynajmniej przez pewien czas ją wykonywał. Warto mieć również na uwadze, iż dyspozycja art. 59 ust. 1 pkt 4a u.g.h. w zasadzie nie pozwala przy ustaleniu niewykonywania przez przedsiębiorcę działalności przez okres krótszy niż 6 miesięcy na cofnięcie mu koncesji z tego powodu, nawet jeżeli okoliczności wskazywałyby, że to niewykonywanie ma charakter „trwały”. Można w tej sytuacji ewentualnie rozważyć, czy miała miejsce „rezygnacja” z prowadzenia działalności, co odpowiada drugiej z przesłanek. W tym miejscu pojawiają się kolejne wątpliwości - po pierwsze, czy rezygnacja z wykonywania działalności może być wyrażona w sposób dorozumiany, czy też jednak należy przyjąć, iż potrzebne jest wyraźne oświadczenie koncesjonariusza w tym przedmiocie. Po drugie, czy zrezygnować z prowadzenia działalności można także przed jej podjęciem, czy dopiero wyłącznie w toku wykonywania działalności.

Odnosząc się do pierwszego z wymienionych problemów, wydaje się, iż należy opowiedzieć się za poglądem dopuszczającym konkludentną rezygnację. Będzie miała ona miejsce, kiedy okoliczności będą wyraźnie przemawiać o zamiarze trwałego zaprzestania wykonywania działalności. Stanowisko to uzasadnione jest zarówno argumentem z wykładni językowej (skoro ustawodawca nie dookreślił formy oświadczenia o rezygnacji, należy dopuścić możliwie szeroki jej zakres), jak i funkcjonalnej (choćby w sytuacji, gdy po podjęciu działalności przedsiębiorca zaprzestałby jej wykonywania, a okoliczności jasno wskazywałyby, iż niewykonywanie ma charakter trwały; zupełnie niecelowe byłoby oczekiwanie z wydaniem decyzji o cofnięciu koncesji do upływu sześciomiesięcznego terminu i zakwalifikowanie tego stanu faktycznego jako ,przerwy” w rozumieniu art. 59 ust. 1 pkt $4 \mathrm{~b}$ u.g.h.).

Natomiast co do kwestii dotyczącej momentu wyrażenia rezygnacji przez koncesjonariusza należy przyjąć, iż jest ono dopuszczalnie jeszcze przed faktycznym podjęciem wykonywania działalności. Co prawda art. 48 ust. 2 u.g.h. przewiduje odrębną sankcję wygaśnięcia koncesji w przypadku nierozpoczęcia działalności $\mathrm{w}$ terminie w niej określonym, przy czym skutek ten następuje ex lege ${ }^{16}$, a ewentu-

15 Dz.U. z 2016 r. poz. 1541.

16 R. Kamionowski, op. cit., s. 149. 
alna decyzja organu w tym przedmiocie ma charakter jedynie deklaratywny. Mimo tego można jednak wyobrazić sobie sytuację, w której określony w koncesji termin rozpoczęcia działalności będzie dość odległy, a koncesjonariusz znacznie wcześniej oświadczy, że rezygnuje z prowadzenia działalności, wówczas zupełnie bezcelowe i zbędne byłoby wyczekiwanie na upływ wyznaczonego terminu połączonego z zaistnieniem skutku z mocy samego prawa, podczas gdy można wcześniej cofnąć koncesję w oparciu o art. 59 ust. 1 pkt 4a u.g.h. Warto w tym miejscu zaznaczyć, iż cofnięcie koncesji z uwagi na niepodjęcie działalności na podstawie art. 58 ust. 1 pkt 2 u.s.d.g. wymaga uprzedniego wezwania organu koncesyjnego do rozpoczęcia działalności; takie wezwanie nie jest natomiast konieczne dla wystąpienia skutku wygaśnięcia $\mathrm{z}$ art. 48 ust. 2 u.g.h. Wreszcie podkreślenia wymaga, iż w sytuacji kiedy przerwa w wykonywaniu koncesji przekracza 6 miesięcy, jednakże w dalszym ciągu nie ma ona charakteru trwałego (przykładowo przedsiębiorca jeszcze przed upływem terminu poinformował, iż planuje wznowić działalność już po upływie 6 miesięcy), nie wystąpi wówczas żadna z okoliczności uzasadniających cofnięcie koncesji w oparciu o przesłanki uregulowane w art. 58 u.s.d.g.

Mając powyższe rozważania na uwadze, uzasadniony jest wniosek, iż przesłanki cofnięcia koncesji na prowadzenie kasyna gry dotyczące rezygnacji lub przerwy w działalności koncesjonowanej (art. 59 ust. 1 pkt 4a-b u.g.h.) wraz z regulacją z art. 48 ust. 2 u.g.h. odnośnie do przypadku wygaśnięcia koncesji obejmują swoją dyspozycją więcej stanów faktycznych, a przez to lepiej chronią interes publiczny niż ich odpowiedniki uregulowane w art. 58 ust. 1 pkt 2 u.s.d.g. W tym zatem zakresie wyłączenie z art. 32 ust. 6 u.g.h. nie wiąże się z negatywnym skutkiem dla ochrony interesu publicznego.

Na podstawie art. 58 ust. 3 u.s.d.g. organ koncesyjny może cofnąć koncesję przy ustaleniu, iż dalsze prowadzenie przez koncesjonariusza działalności gospodarczej niesie za sobą zagrożenie obronności lub bezpieczeństwa państwa bądź obywateli. Wskazane pojęcia to klasyczne klauzule generalne o nader szerokiej pojemności semantycznej, które są dookreślane już na etapie stosowania prawa przez właściwy organ i przy wzięciu pod uwagę całości materiału prawno-faktycznego występującego w sprawie. Ocena zaktualizowania się tej klauzuli generalnej w konkretnych okolicznościach łączy się ze stosowaniem pewnej uznaniowości przez badający tę kwestię organ ${ }^{17}$.

Starając się jednak zdefiniować te wyrażenia, można wskazać, iż obronność państwa sprowadza się do ,jego zdolności militarnej do przeciwstawienia się agresji zarówno ze strony innych państw, jak i ewentualnych sił wewnętrznych"18, z kolei bezpieczeństwo państwa to „stan wolny od różnego rodzaju zagrożeń wewnętrznych i zewnętrznych, umożliwiający zachowanie substancji narodowej

17 S. Koroluk, [w:] Ustawa o swobodzie działalności gospodarczej. Komentarz, red. A. Powałowski, Warszawa 2009, s. 234.

18 K. Kohutek, [w:] M. Brożyna et al., Komentarz do ustawy o swobodzie działalności gospodarczej. Kom. do art. 56, LEX/el. 2005, nb. 1. 
i możliwości niezakłóconego współżycia w społeczności”19. Wreszcie zagrożenie dla bezpieczeństwa obywateli odnosi się do „sytuacji, w której powstaje realne zagrożenie dla podstawowych wartości jednostek, jakimi są ich życie i zdrowie"20.

Odwołania do tej klauzuli generalnej brakuje natomiast przy regulacji przesłanek cofnięcia koncesji na prowadzenie kasyna gry. Ustawodawca wymienił za to kilka okoliczności odwołujących się pośrednio do bezpieczeństwa państwa lub obywateli, w tym wymóg utrzymywania przez cały okres wykonywania działalności kapitału zakładowego na określonym, wysokim kwotowo poziomie (art. 59 ust. 1 pkt 3 u.g.h.), okoliczność dotyczącą skazania osób sprawujących funkcje właścicielskie, zarządzające i kontrolne w spółce koncesjonariusza za sprecyzowany rodzaj przestępstw (art. 59 ust. 1 pkt 5 u.g.h.), naruszenie przez koncesjonariusza przepisów dotyczących przeciwdziałania praniu pieniędzy oraz finansowania terroryzmu lub przepisów o rachunkowości (art. 59 ust. 1 pkt 7-8 u.g.h.) czy też przypadek dwukrotnego stwierdzenia udziału $\mathrm{w}$ grach hazardowych $\mathrm{w}$ tym samym ośrodku gier osoby poniżej 18. roku życia (art. 59 ust. 1 pkt 6 u.g.h.). Ta ostatnia przesłanka podkreśla specyficzną troskę ustawodawcy o bezpieczeństwo osób niepełnoletnich jako kategorii ludzkiej wyjątkowo narażonej na negatywne skutki oddziaływania hazardu w społeczeństwie, co obejmuje przede wszystkim ryzyko uzależnienia.

Wydaje się, iż ustawodawca przez zaniechanie umiejscowienia wśród przesłanek cofnięcia koncesji na prowadzenia kasyna gry okoliczności odnoszącej się wprost do zagrożenia bezpieczeństwa państwa lub ludzi niepotrzebnie przymyka furtę organom koncesyjnym na etapie stosowania prawa, ograniczając wydatnie możliwość odebrania koncesji w przypadkach nieobjętych dyspozycją enumeratywnie wymienionych przesłanek nawiązujących jedynie do wzmiankowanych wartości. Niemożliwie jest bowiem przewidzenie w momencie redagowania tekstu prawnego wszystkich okoliczności faktycznych, jakie mogą zaistnieć w pewnej sferze, przez co część z nich może nie zmieścić się w dyspozycji normy wyrażonej w przepisie i nie zostać konsekwentnie objęta skutkami prawnym. Zachodzi to szczególnie często właśnie w sytuacjach kształtowania dyspozycji normy z wykorzystaniem enumeratywnego wyliczenia. W tym zakresie norma wyłączająca wyrażona w art. 32 ust. 6 u.g.h. niewątpliwie poszerza swobodę prowadzenia działalności gospodarczej, jednakże kosztem ochrony uzasadnionego, jak się wydaje, interesu publicznego.

Kolejną okolicznością uregulowaną wyłącznie w charakterze ogólnej przesłanki cofnięcia koncesji (ale już nie przesłanki cofnięcia koncesji na prowadzenie kasyna gry) jest ogłoszenie upadłości przedsiębiorcy na podstawie art. 58 ust. 3 u.s.d.g. Także w tym wypadku dziwić może pominięcie tej okoliczności przez ustawodawcę przy regulacji z u.h.g. Tym bardziej że część ukonstytuowa-
19 Ibidem.
20 Ibidem. 
nych tam przesłanek świadczy o tym, jak dużą wagę ustawodawca przykłada do konieczności zapewnienia możliwości wykonywania działalności związanej $\mathrm{z}$ urządzaniem koncesjonowanych gier hazardowych jedynie przez przedsiębiorcę charakteryzującego się znacznym potencjałem finansowym i stabilną sytuacją ekonomiczną (nawiązuje do tego choćby wymóg utrzymania i posiadania kapitału zakładowego w kwocie $4000000 \mathrm{zl}$ - art. 10 ust. 1 pkt 1 u.g.h. i art. 59 ust. 1 pkt 3 u.g.h. — czy też konieczność respektowania przepisów o rachunkowości art. 59 ust. 1 pkt 8 u.g.h.).

Wydaje się, iż brak tu pewnej konsekwencji i spójności w działaniach legislacyjnych. W myśl bowiem art. 10 p.u. „upadłość ogłasza się w stosunku do dłużnika, który stał się niewypłacalny", przy czym definicję niewypłacalności i kwestie z nią związane reguluje dodatkowo art. 11 p.u., stosownie do którego „dłużnik jest niewypłacalny, jeżeli utracił zdolność do wykonywania swoich wymagalnych zobowiązań pieniężnych” (ust. 1). Nadto „domniemywa się, że dłużnik utracił zdolność do wykonywania swoich wymagalnych zobowiązań pieniężnych, jeżeli opóźnienie w wykonaniu zobowiązań pieniężnych przekracza trzy miesiące" (ust. 1a), z kolei

dłużnik będący osobą prawną albo jednostką organizacyjną nieposiadającą osobowości prawnej, której odrębna ustawa przyznaje zdolność prawną, jest niewypłacalny także wtedy, gdy jego zobowiązania pieniężne przekraczają wartość jego majątku, a stan ten utrzymuje się przez okres przekraczający dwadzieścia cztery miesiące (ust. 2).

W obecnym stanie prawnym, o ile nie zajdą przy okazji inne przesłanki z art. 59 ust. 1 u.g.h., organ koncesyjny nie ma kompetencji do cofnięcia koncesji koncesjonariuszowi, w stosunku do którego ogłoszono upadłość, co siłą rzeczy wiąże się z utratą przez niego płynności finansowej, przy czym nie pozbawia go jednocześnie możliwości prowadzenia działalności gospodarczej. Jest to zatem kolejny przykład, gdzie na skutek wyłączenia z art. 32 ust. 6 u.g.h. ochrona interesu publicznego w odniesieniu do sfery działalności gospodarczej dotyczącej urządzania koncesjonowanych gier hazardowych jest znacznie ukrócona.

\section{Wnioski}

Podsumowując, przeprowadzone porównanie przesłanek cofnięcia koncesji uregulowanych $\mathrm{w}$ u.s.d.g oraz u.g.h. pozwala stwierdzić, iż jedynie w pewnym zakresie pokrywają się one, w innym natomiast ich dyspozycje obejmują zróżnicowane sytuacje. Jednakże mocą art. 32 ust. 6 u.g.h. w sprawach dotyczących m.in. cofnięcia koncesji na prowadzenie kasyna gry wyłączone jest stosowanie przesłanek ogólnych, przez co regulacja zawarta w u.g.h. w tym zakresie zyskuje cechy pełnej samodzielności oraz kompletności. 
Przyjęcie takiego rozwiązania legislacyjnego musi dziwić. Jego efektem jest bowiem istotne ograniczenie kompetencji organu koncesyjnego do cofnięcia koncesji na prowadzenie kasyna gry. $Z$ jednej strony skutkuje to niewątpliwie poszerzeniem sfery wolności gospodarczej, z drugiej natomiast naraża na uszczerbek interes publiczny poprzez dopuszczenie w szerszych granicach negatywnych oddziaływań hazardu w społeczeństwie. Co więcej, wyłączenie stosowania przesłanek o charakterze ogólnym nie ma odpowiednika w treści innych ustaw szczególnych, konstytuujących dodatkowe przesłanki cofnięcia koncesji, gdzie zyskują one charakter jedynie uzupełniający (a nie zastępujący) w stosunku do regulacji lex generalis. Rozstrzygając w przedmiocie cofnięcia koncesji na prowadzenie kasyna gry, organ koncesyjny nie może choćby powołać się na ogólną klauzulę zagrożenia bezpieczeństwa państwa lub obywateli bądź też fakt ogłoszenia upadłości przez koncesjonariusza. Nie ma natomiast przeszkód, by okoliczności te stanowiły podstawę decyzji negatywnej w odniesieniu do każdego innego rodzaju koncesjonowanej działalności gospodarczej.

Dostrzegalny jest w tym zakresie brak spójności działań ustawodawcy, który przecież poprzez wprowadzenie licznych obostrzeń w odniesieniu do prowadzenia działalności gospodarczej w branży hazardowej, z wymogiem uzyskania koncesji na urządzanie niektórych rodzajów gier hazardowych włącznie, zdawał się obrać przeciwległy kurs przy regulacji tej sfery życia społeczno-gospodarczego, maksymalizując w tym zakresie ochronę interesu publicznego kosztem właśnie wolności gospodarczej jednostki.

\title{
Exclusion of the application provisions of freedom of economic activity act in the scope of concession for operating casino games and the protection of the public interest
}

\author{
Summary
}

This article presents the comparison between provisions of freedom of economic activity act and the law on gambling in scope of conditions related to revoking concession for operating casino games. To revoke that concession, only provisions of law on gambling can be applied because of provisions of freedom of economic activity act are excluded in that cases. That regulation allows the raising of freedom economic activity, but the other hand - also causes the limitation in the protection of public interest.

Keywords: gambling, revoke, concession, casino, exclude. 